\title{
Lymphoplasmacytic Lymphoma
}

National Cancer Institute

\section{Source}

National Cancer Institute. Lymphoplasmacytic Lymphoma. NCI Thesaurus. Code C3212.

A clonal neoplasm of small B-lymphocytes, lymphoplasmacytoid cells, and plasma cells involving the bone marrow, lymph nodes, and the spleen. The majority of patients have a serum Ig M paraprotein. 